\title{
Adjustment of mathematical models and quality of soybean grains in the drying with high temperatures
}

\author{
Paulo C. Coradi ${ }^{1}$, Carlos H. P. Fernandes ${ }^{1} \&$ Jean C. Helmich ${ }^{1}$ \\ ${ }^{1}$ Universidade Federal de Mato Grosso do Sul. Chapadão do Sul, MS. E-mail: paulo.coradi@ufms.br (Corresponding author); c.h.p.f_@hotmail.com; \\ jeancarloshelmich@hotmail.com
}

\section{Key words: \\ dimensioning \\ optimization \\ post-harvest}

\begin{abstract}
A B S T R A C T
The aim of this study was to evaluate the influence of the initial moisture content of soybeans and the drying air temperatures on drying kinetics and grain quality, and find the best mathematical model that fit the experimental data of drying, effective diffusivity and isosteric heat of desorption. The experimental design was completely randomized (CRD), with a factorial scheme $(4 \times 2)$, four drying temperatures $\left(75,90,105\right.$ and $\left.120^{\circ} \mathrm{C}\right)$ and two initial moisture contents ( 25 and $19 \%$ d.b.), with three replicates. The initial moisture content of the product interferes with the drying time. The model of Wang and Singh proved to be more suitable to describe the drying of soybeans to temperature ranges of the drying air of 75, 90, 105 and $120^{\circ} \mathrm{C}$ and initial moisture contents of 19 and $25 \%$ (d.b.). The effective diffusivity obtained from the drying of soybeans was higher $\left(2.5 \times 10^{-11} \mathrm{~m}^{2} \mathrm{~s}^{-1}\right)$ for a temperature of 120 ${ }^{\circ} \mathrm{C}$ and water content of $25 \%$ (d.b.). Drying of soybeans at higher temperatures (above 105 ${ }^{\circ} \mathrm{C}$ ) and higher initial water content ( $25 \%$ d.b.) also increases the amount of energy $(3894.57$ $\mathrm{kJ} \mathrm{kg}^{-1}$ ), i.e., the isosteric heat of desorption necessary to perform the process. Drying air temperature and different initial moisture contents affected the quality of soybean along the drying time (electrical conductivity of $540.35 \mu \mathrm{S} \mathrm{cm}^{-1} \mathrm{~g}^{-1}$ ); however, not affect the final yield of the oil extracted from soybean grains (15.69\%).
\end{abstract}

\section{Palavras-chave:}

dimensionamento

otimização

pós-colheita

\section{Ajustes de modelos matemáticos e qualidade de grãos de soja na secagem com altas temperaturas}

\section{R E S U M O}

O objetivo deste estudo foi avaliar a influência do teor de água inicial da soja e as temperaturas do ar de secagem sobre a cinética de secagem, qualidade do grão e encontrar o melhor modelo matemático que se ajustar aos dados de secagem experimental, a difusividade efetiva e o calor isostérico de dessorção. Foi adotado o delineamento experimental inteiramente casualisado (DIC) com esquema fatorial (4 x 2), quatro temperaturas de secagem (75, 90,105 e $\left.120^{\circ} \mathrm{C}\right)$ e dois teores de água inicial ( 25 e 19\% b.s.) com três repetições. O teor de água inicial do produto interferiu no tempo de secagem. O modelo de Wang e Singh mostrou-se mais adequado para descrever o processo de secagem dos grãos de soja para as faixas de temperaturas do ar de secagem de $75,90,105$ e $120^{\circ} \mathrm{C}$ e teores de água iniciais de 19 e $25 \%$ (b.u.). A difusividade efetiva obtida da secagem dos grãos de soja foi maior $\left(2,5 \times 10^{-11} \mathrm{~m}^{2} \mathrm{~s}^{-1}\right)$ para a temperatura de $120^{\circ} \mathrm{C}$ e teores de água de $25 \%$ (b.s.). A secagem dos grãos de soja com temperaturas mais elevadas (acima de $105^{\circ} \mathrm{C}$ ) e com maior teor de água inicial (25\% b.u.) aumentou também a quantidade de energia $\left(3894,57 \mathrm{~kJ} \mathrm{~kg}^{-1}\right)$, ou seja, o calor isostérico de dessorção necessário para realizar o processo. A temperatura do ar de secagem e dos diferentes teores de água inicial afetou a qualidade dos grãos de soja ao longo do tempo de secagem (condutividade elétrica de $540,35 \mu \mathrm{Sm}^{-1} \mathrm{~g}^{-1}$ ), no entanto, não interferiu no rendimento de óleo final extraído dos grãos de soja $(15,69 \%)$. 


\section{INTRODUCTION}

Soybean is one of the main cereals in the world, and Brazil accounts for $40 \%$ of the total grain production. This cereal is responsible for $27 \%$ of the global market. Brazil is the second largest producer and the largest exporter (CONAB, 2014). Soybeans are often harvested with water content between 16 and $18 \%$, making it necessary to subject them to drying, in order to prevent enzymatic reactions and the development of fungi and microorganisms that produce hydrolytic enzymes such as lipases, leading to an increase of free fatty acids, which affect the quality of the grains (Ullmann et al., 2010). In a mass of moisture grain, this water vapor tends to occupy all the intercellular spaces, generating pressures in all directions.

Moreover, this drying air in the form of water vapor also exerts a partial pressure, designated as partial pressure of water vapor in air (Coradi et al., 2014a). Thus, the drying process aims to partially remove water from the grains, through the simultaneous transfer of heat from the air to the kernels and mass flow through the water vapor, from the beans into the air (Goneli et al., 2011; Siqueira et al., 2012). According to Corrêa et al. (2010), information about the behavior of the phenomenon of heat and mass transfer between the biological material and the element of drying is essential for design, operation simulations of drying, dryers and grain quality systems. From the drying curves of soybeans, moisture data versus time can be adjusted (Corrêa et al., 2010; Goneli et al., 2011; Coradi et al., 2014b).

The study on drying systems, their dimensioning, optimization and determining the feasibility of their commercial application can be made by mathematical simulation, whose principle is based on the successive thin layers of drying of the product, using a mathematical model. The use of mathematical models to simulate the drying process in dryers operating at high temperature is an important tool for engineers working in the field of drying and storing grains (Corrêa et al., 2010; Goneli et al., 2011; Coradi et al., 2014b). There are numerous kinetic models of drying.

Drying of hygroscopic products can be described by theory, empirical and semi-theoretical methods. Theoretical methods usually consider the external conditions under which the operation occurs, as well as the internal mechanisms of energy transfer and mass and their effects. Brooker et al. (1992) cite the example of theoretical models for the hydrodynamic flow and broadcasts: liquid, capillary surface, steam and heat. Semitheoretical models are based on Newton's cooling law applied to mass transfer, assuming that the conditions are isothermal and that the water transfer resistance is restricted only to the surface of the product (Brooker et al., 1992). Among semitheoretical models, the model of two terms, Henderson \& Pabis and Page have been widely used (Ullmann et al., 2010; Coradi et al., 2014b). According to Ullmann et al. (2010), the rule of thumb is to form physical dimensionless groups that can be easily investigated by laboratory experiments and is based on external conditions such as temperature, mixing ratio and speed of the drying air. Among these models, there are Thompson, Peart \& Foster and Wang \& Singh, traditionally used in studies of drying agricultural products and foodstuff
(Martinazzo et al., 2010; Oliveira et al., 2013; Nascimento et al., 2015).

Thus, the aim of this study was to evaluate the influence of the initial water content of the soybeans and the temperatures of the drying air on drying kinetics and grain quality, as well as to find the best mathematical model that fit the experimental data of drying, effective diffusivity and isosteric heat of desorption.

\section{Material ANd Methods}

The experiment was conducted at the Federal University of Mato Grosso do Sul (UFMS), Campus of Chapadão do Sul (CPCS), at the Postharvest of Agricultural Products Laboratory, in the year of 2013. The soybean grains were harvested at random with 25 and $19 \%$ (d.b.) of moisture content, and the impurities was taken damaged grains using manual separation. Then, the grains were dried in a convection oven with forced air ventilation at temperatures of $75,90,105$ and $120^{\circ} \mathrm{C}$. Drying was carried out until the seeds reached the hygroscopic moisture balance. For each temperature of the drying air, three tests were performed and, for each test, $5 \mathrm{~kg}$ of soybean grains were used. The temperature and relative humidity were monitored throughout drying with the aid of a psychrometer.

The moisture content of grains (\% d.b.) was determined by weighing $15 \mathrm{~g}$ of sample. Then, the samples were placed in an oven with air heating and ventilation regulated at $105 \pm 1{ }^{\circ} \mathrm{C}$ for $24 \mathrm{~h}$, according to the recommendations of Brasil (2009). After that, the samples were removed and placed in desiccators for cooling. The moisture content (\% d.b.) was determined by mass difference between the initial and the final sample. Tests were performed in three replicates.

The drying curves were fitted to the experimental data using thirteen different semi-empirical and empirical equations (Eqs. 1 to 11$)$, discriminated below:

- Newton

$$
R X=\exp (-k \cdot t)
$$

- Page

$$
\mathrm{RX}=\exp \left(-\mathrm{k} \cdot \mathrm{t}^{\mathrm{n}}\right)
$$

- Page Modified

$$
R X=\exp \left[-(k \cdot t)^{n}\right]
$$

- Henderson \& Pabis

$$
\mathrm{RX}=\mathrm{a} \cdot \exp (-\mathrm{k} \cdot \mathrm{t})
$$

- Logarithmic

$$
\mathrm{RX}=\mathrm{a} \cdot \exp (-\mathrm{k} \cdot \mathrm{t})+\mathrm{c}
$$

- Two Terms

$$
R X=a \cdot \exp \left(-k_{0} \cdot t\right)+b \cdot \exp \left(-k_{1} \cdot t\right)
$$


- Two Exponential Terms

$$
\mathrm{RX}=\mathrm{a} \cdot \exp (-\mathrm{k} \cdot \mathrm{t})+(1-\mathrm{a}) \exp (-\mathrm{k} \cdot \mathrm{a} \cdot \mathrm{t})
$$

- Wang \& Singh

$$
\mathrm{RX}=1+\mathrm{a} \cdot \mathrm{t}+\mathrm{b} \cdot \mathrm{t}^{2}
$$

- Henderson \& Pabis

$$
\mathrm{RX}=\mathrm{a} \cdot \exp (-\mathrm{k} \cdot \mathrm{t})+\mathrm{b} \cdot \exp \left(-\mathrm{k}_{0} \cdot \mathrm{t}\right)+\mathrm{c} \cdot \exp \left(-\mathrm{k}_{1} \cdot \mathrm{t}\right)
$$

- Midilli

$$
\mathrm{RX}=\mathrm{a} \cdot \exp \left(-\mathrm{k} \cdot \mathrm{t}^{\mathrm{n}}\right)+\mathrm{b} \cdot \mathrm{t}
$$

- Diffusion Approximation

$$
\mathrm{RX}=\mathrm{a} \cdot \exp (-\mathrm{k} \cdot \mathrm{t})+(1-\mathrm{a}) \cdot \exp (-\mathrm{k} \cdot \mathrm{b} \cdot \mathrm{t})
$$

where:

RX - moisture ratio, dimensionless;

t - drying time, h;

$\mathrm{k}, \mathrm{k}_{\mathrm{o}}, \mathrm{k}_{1}$ - drying constant, $\mathrm{h}^{-1}$; and,

$\mathrm{a}, \mathrm{b}, \mathrm{c}, \mathrm{n}$ - model coefficients.

For determining the ratios of moisture during drying under different conditions, the following expression (Eq. 12) was used:

$$
\mathrm{RU}=\frac{\mathrm{U}-\mathrm{Ue}}{\mathrm{Ui}-\mathrm{Ue}}
$$

where:

$\mathrm{U}$ - moisture content of the product, d.b.;

Ui - initial moisture content of the product, d.b.; and,

Ue - equilibrium moisture content of the product, d.b.

It is usual to consider the value of the diffusion coefficient constant or linearly dependent on the temperature of the air drying. This relationship has been expressed by the Arrhenius model (Mohapatra \& Rao, 2005), Eq. 13:

$$
\mathrm{D}=\mathrm{A} \exp \left(-\frac{\mathrm{E}}{\mathrm{RT}}\right)
$$

where:

$$
\begin{array}{ll}
\mathrm{A} & \text { - constant, } \mathrm{m}^{2} \mathrm{~s}^{-1} ; \\
\mathrm{E} & \text { - activation energy, } \mathrm{kJ} \mathrm{kmol} \\
\mathrm{R} & \text { - universal gas constant, } 8,314 \mathrm{~kJ} \mathrm{kmol}^{-1} \mathrm{~K}^{-1} \text {; and, } \\
\mathrm{T} & \text { - absolute temperature, } \mathrm{K} .
\end{array}
$$

The coefficients of the Arrhenius expression were linearized by applying the logarithm of the form (Eq. 14):

$$
\mathrm{LnD}=\mathrm{LnA}-\frac{\mathrm{E}}{\mathrm{RT}} \frac{1}{\mathrm{Ta}}
$$

The values of water activity, temperature and equilibrium moisture content were obtained from the soybean grains desorption isotherms, using the model that best fitted the experimental data. For the calculation of the integral isosteric heat of desorption, it was used the following expression, Eq. 15:

$$
\mathrm{Q}_{\mathrm{st}}=\mathrm{q}_{\mathrm{st}}+\mathrm{L}=\mathrm{a} \cdot \exp (-\mathrm{b} \cdot \mathrm{Ue})+\mathrm{L}
$$

where:

$\mathrm{Q}_{\mathrm{st}} \quad$ - integral isosteric heat of sorption, $\mathrm{kJ} \mathrm{kg}^{-1}$;

$\mathrm{L} \quad$ - latent heat of vaporization of free water, $\mathrm{kJ} \mathrm{kg}^{-1}$; and,

a, b - coefficients of the model.

The free water latent heat of vaporization (Mohapatra \& Rao, 2005) was obtained using the average temperature according to Eq. 16:

$$
\mathrm{L}=2502.3-2.39 \mathrm{~T}_{\mathrm{m}}
$$

where:

$\mathrm{L} \quad$ - latent heat of vaporization of free water, $\mathrm{kJ} \mathrm{kg}^{-1}$; and,

$\mathrm{T}_{\mathrm{m}}$ - average temperature, ${ }^{\circ} \mathrm{C}$.

To adjust the mathematical models of analysis of drying grains, nonlinear regression was performed, through the Quasi-Newton method, using the computer program Statistica $7.0^{\circ}$. To check the degree of fit of each model, the significance of the regression coefficient by t-test was considered, adopting the 0.05 level of probability, the magnitude of the coefficient of determination $\left(\mathrm{R}^{2}\right)$, the mean relative error values $(\mathrm{P})$ (Eq. 17) and the average estimated error (SE) (Eq. 18) and verified the behavior of distribution of residuals. The relative average error and the average error estimated for each model were calculated according to the following expressions, respectively:

$$
\begin{gathered}
\mathrm{P}=\frac{100}{\mathrm{n}} \sum \frac{|\mathrm{Y}-\hat{\mathrm{Y}}|}{\mathrm{Y}} \\
\mathrm{SE}=\sqrt{\frac{\sum(\mathrm{Y}-\hat{\mathrm{Y}})^{2}}{\mathrm{GLR}}}
\end{gathered}
$$

where:

Y - experimentally observed value;

$\hat{Y} \quad$ - value calculated by the model;

$\mathrm{n}$ - number of experimental observations; and,

GLR - degrees of freedom of the model (the number of observations minus the number of model parameters).

The electrical conductivity test was conducted in sunflower seeds, according to the methodology described by Vieira \& Krzyzanowski (1999). To analyse the yield of oil in soybean grains, the methodology described by Oliveira et al. (2013) was used.

The experiment was arranged in a completely randomized design (CRD) in a factorial scheme ( $4 \times 2)$, and the treatments consisted of four drying air temperatures (75, 90, 105 and 120 
${ }^{\circ} \mathrm{C}$ ) and two initial moisture contents of soybean grains (19 and $25 \%$ d.b.) with three replicates. The data for oil yield and electrical conductivity were analysed by analysis of variance, using the Tukey test at 0.01 and 0.05 probabilities.

\section{Results AND Discussion}

The drying process aimed at the partial removal of water from the grains, through the simultaneous transfer of heat and the air mass flow through the water vapor in the air to the grains (Goneli et al., 2011; Coradi et al., 2014a). Figure $1 \mathrm{~A}$ shows the curves of drying of soybean under different conditions of temperature and initial moisture content. It was found that the drying time of the soybeans, considering the reduction of the moisture content from 0.19 to 0.11 (decimal, d.b.) was $2.33 \mathrm{~h}$ for the temperature of $75^{\circ} \mathrm{C}$. Figure 1 shows that the content for the temperature of $120^{\circ} \mathrm{C}$ is greater than that observed at 75,90 , and $105^{\circ} \mathrm{C}$. However, as the drying process continues toward the equilibrium moisture content, the drying representative curves are similar, differing in the time of drying. After 1 hour of drying the product subjected to a temperature of $120^{\circ} \mathrm{C}$, the moisture content reached $11.8 \%$ (d.b.), while for the drying at 75,90 , and $105^{\circ} \mathrm{C}$, the moisture contents were $17.5,16.5$, and $12 \%$ (d.b.), respectively. The drying curves for the soybean grains adjusted to the Wang \& Singh model at temperatures of $75,90,105$ and $120{ }^{\circ} \mathrm{C}$, and initial moisture content of $19 \%$ (d.b.). It was found that the satisfactory adjustment was predicted by Wang \& Singh curves to the experimental data model, regardless of the conditions tested (Figure 1B).

The coefficients of the adjusted models, analysed during drying of soybean grains at different drying air temperatures for initial moisture content of $19 \%$ (d.b.) are shown in Table 1. Among the models that gave good statistical results (Table 1), the Wang \& Singh model was selected to represent the phenomenon of drying of soybean grains due to its simplicity compared to other models and also was selected to present a number of significant coefficients. From the Wang \& Singh model, it was observed that the drying coefficients "a" and "b" increased with increasing temperature, except at the temperature of $90{ }^{\circ} \mathrm{C}$.

The coefficients "a" and "b" represent the effects of external drying conditions, according to Babalis \& Belessiotis (2004), and can be used as an approach to characterize the effect of temperature related to the effective diffusivity in the drying process period and the descending liquid diffusion controlling the process. On the other hand, the constant " $n$ " reflects the internal strength of the product drying. For Corrêa et al. (2006), the Verma model satisfactorily represented the Coffea arabica fruits phenomenon of drying. However, Coradi et al. (2014b) evaluated coffee grains and verified that the Midilli model adjusted best to the kinetics of drying.

Babalis \& Belessiotis (2004) noted that the model of Two Terms showed the best fit to the experimental data of fig and dried seaweeds (Gelidium sesquipedale), respectively. Martinazzo et al. (2010) found that the best model for drying sheets of lemon grass is the Midilli model, which also considered flat plate and noticed that the drying coefficient "k" increased with increasing temperature, and the constant " $n$ " decreased, confirming the data obtained in this study. A similar result was found by Radünz et al. (2010), who studied sage leaves drying conditions under room temperature between 40 and $90^{\circ} \mathrm{C}$ and concluded that the models Handerson, Pabis, and Midilli were the ones that the best represented the drying kinetics for sage leaves.

The coefficient of determination is a good parameter to check the fit of nonlinear models and typically has higher values for the models that best fit the experimental data. Thus, it was observed that for most treatments, the coefficients of determination $\mathrm{R}^{2}$ were above 0.97 , indicating, according
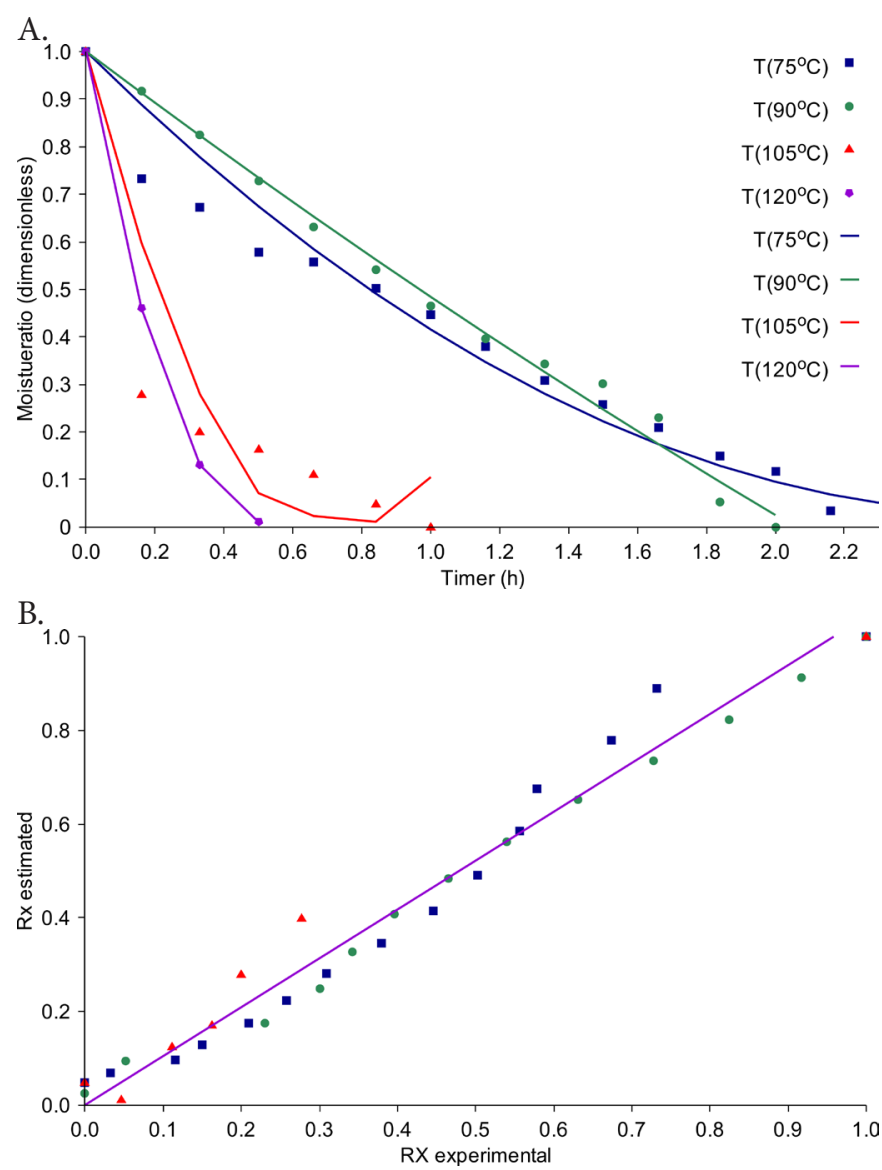

Figure 1. Moisture ratio (A) adjusted, experimental data and estimated moisture ratio (B) by the Wang \& Singh model, for $19 \%$ (d.b.) of initial moisture content

Table 1. Parameters obtained, coefficient of determination $\left(R^{2}\right)$, mean relative error $(P)$, estimated values of average error (SE) and distribution residue (DR) from Wang and Singh model fitted to the data of drying of soybean grains for $19 \%$ (d.b.) of initial water content

\begin{tabular}{|c|c|c|c|c|c|c|c|}
\hline Wang and Singh model & $\bar{T}\left({ }^{\circ} \mathrm{C}\right)$ & a & b & $\mathrm{R}^{2}$ & SE (decimal) & $\overline{P(\%)}$ & DR \\
\hline \multirow{4}{*}{$\mathrm{RU}=1+\mathrm{at}+\mathrm{bt}^{2}$} & 75 & -0.718800 & 0.132126 & 0.9947 & 0.0267 & 2.20 & A \\
\hline & 90 & -0.544800 & 0.028610 & 0.9957 & 0.0103 & 3.14 & A \\
\hline & 105 & -2.820600 & 1.925448 & 0.9959 & 0.0170 & 2.37 & $A$ \\
\hline & 120 & -4.050820 & 4.181176 & 0.9930 & 0.0260 & 2.30 & A \\
\hline
\end{tabular}


to Corrêa et al. (2006), a satisfactory representation of the phenomenon under study. The Wang \& Singh model showed the lowest values of the mean relative error $(\mathrm{P})$, average estimated error (SE) and distribution of residues for the air drying temperatures of $75,90,105$, and $120^{\circ} \mathrm{C}$, and initial moisture content of $19 \%$ (d.b.) (Table 1).

The successful adjustment obtained by the Wang \& Singh model occurred because the drying of soybeans occurred in the falling rate period, wherein the greater resistance to heat and mass transfer occurs from the product to the surface. It appears that during the drying the effective diffusion coefficient increased significantly $(\mathrm{p}<0.05)$, with the rise of temperature (Figure 2A). Almeida et al. (2009) found that during the drying of adzuki, effective diffusion coefficients had magnitudes between $0.51 \times 10^{-10}$ and $2.23 \times 10^{-10} \mathrm{~m}^{2} \mathrm{~s}^{-1}$ for the temperature above at $30{ }^{\circ} \mathrm{C}$.

The linear fit obtained indicates a uniform variation of diffusivity with temperature, the value being the variation of diffusivity coefficient obtained at 105 and $120^{\circ} \mathrm{C}$, slightly higher than the temperatures of 75 and $90{ }^{\circ} \mathrm{C}$ (Figure 2A) This may be explained by the molecular vibration of water, because, according to Goneli et al. (2011), the effective diffusion coefficient of variation occurs with increasing temperature, which increases the molecular vibration of water molecules and contributes to a faster diffusion. It is observed that the values of $\operatorname{Ln}(\mathrm{D})$ as a function of the inverse absolute temperature (1/ $\mathrm{Ta}$ ) show similar behavior for the ranges of temperature 75 to $90{ }^{\circ} \mathrm{C}$ and 105 to $120^{\circ} \mathrm{C}$ (Figure 2B). Thus, it can be inferred that there was no interference of external conditions on the drying temperatures. The observed activation energy increased with the increase of air temperature of drying (Figure 2C). The activation energy is a barrier that must be overcome so that the diffusion process can be triggered in the product (Kashaninejad et al., 2007; Reis et al., 2011).

Figure $3 \mathrm{~A}$ shows that the drying time of the soybeans, considering the reduction of the moisture content from 0.25 to 0.11 (decimal, d.b.), was $3.7 \mathrm{~h}$ for the temperature of 75 ${ }^{\circ} \mathrm{C}$; however, in the drying at $120^{\circ} \mathrm{C}$ the time to complete the process was $0.7 \mathrm{~h}$. Thus, it was observed that, with increasing air temperature, the drying time decreased, showing greater water removal rate of the grains. This happened because of the increased availability of energy for vaporization of the water and increase in the coefficient of mass transfer by increasing the temperature of the drying air. It is observed in Figure $3 \mathrm{~A}$ that, in the first $0.3 \mathrm{~h}$ of the process, the drying rate at 120 and $105^{\circ} \mathrm{C}$ is greater than that observed at 75 and $90^{\circ} \mathrm{C}$. However, as the drying process continues toward the equilibrium moisture content, the representative curves of drying at 75 , 90 , and $105^{\circ} \mathrm{C}$ were above the curve at $105^{\circ} \mathrm{C}$, indicating a possible change in the mechanisms that govern the internal

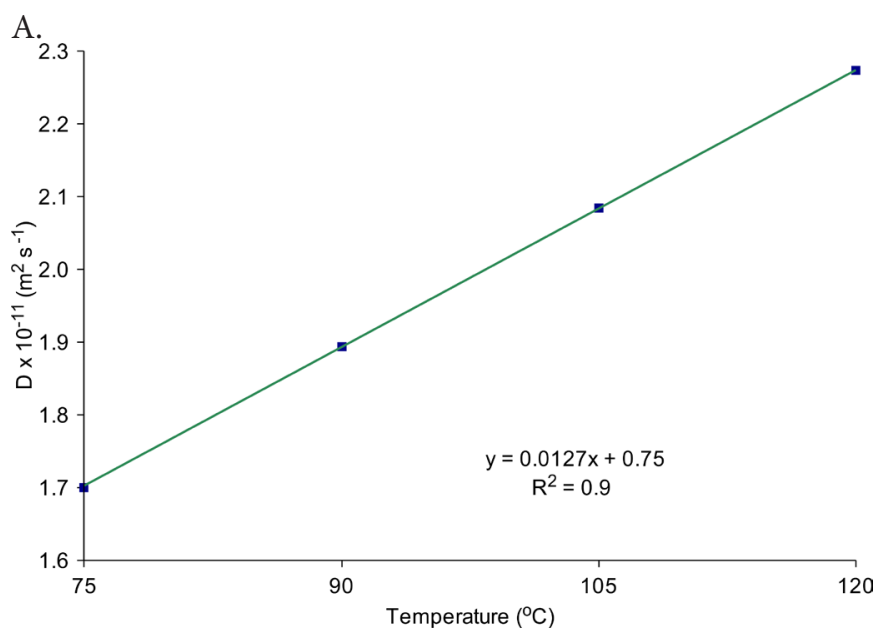

B.

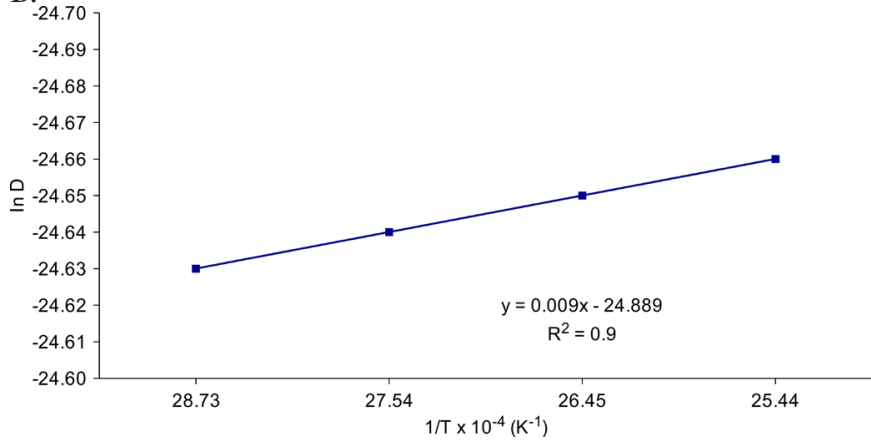

C.

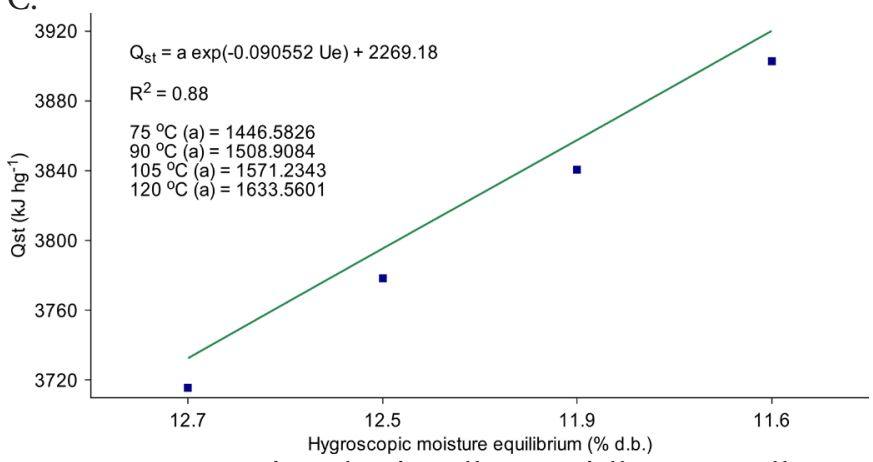

Figure 2. Mean values for the effective diffusion coefficient $\left(\mathrm{m}^{2} \mathrm{~s}^{-1}\right)(\mathrm{A})$, representation of the Arrhenius relationship for the effective diffusivity (B), experimental values and estimated integral isosteric heat of desorption as a function of equilibrium moisture content $(\mathrm{C})$, due to different air temperatures in the drying for $19 \%$ (d.b.) of initial moisture content of soybeans grains

movement of moisture. In any event, after $0.3 \mathrm{~h}$ drying, the product subjected to a temperature of $120^{\circ} \mathrm{C}$ reached water content of $13 \%$ (d.b.), while those dried at 75,90 , and $120^{\circ} \mathrm{C}$ reached 31,28 , and $17 \%$ (d.b.), respectively.

From $0.3 \mathrm{~h}$ of drying, the product being dried at $75^{\circ} \mathrm{C}$ has certainly greater amount of free water to provide higher

Table 2. Parameters obtained, coefficient of determination $\left(R^{2}\right)$, mean relative error $(P)$, estimated values of average error (SE) and distribution residue (DR) from Wang \& Singh model fitted to the data of drying of soybean grains for $25 \%$ (d.b.) of initial moisture content

\begin{tabular}{cccccccc}
\hline Wang \& Singh model & $\mathbf{T}\left({ }^{\circ} \mathbf{C}\right)$ & $\mathbf{a}$ & $\mathbf{b}$ & $\mathbf{R}^{2}$ & SE (decimal) & $\mathbf{P}(\%)$ & $\mathbf{D R}$ \\
& 75 & -0.284900 & 0.002680 & 0.9957 & 0.0361 & 1.01 & $\mathrm{~A}$ \\
$\mathrm{RU}=1+\mathrm{at}+\mathrm{bt}^{2}$ & 90 & -0.462100 & 0.039562 & 0.9992 & 0.0274 & 0.45 & $\mathrm{~A}$ \\
& 105 & -1.588280 & 0.614766 & 0.9990 & 0.0254 & 1.10 & $\mathrm{~A}$ \\
& 120 & -4.089220 & 4.080789 & 0.9968 & 0.0171 & 1.52 & $\mathrm{~A}$ \\
\hline
\end{tabular}


A.

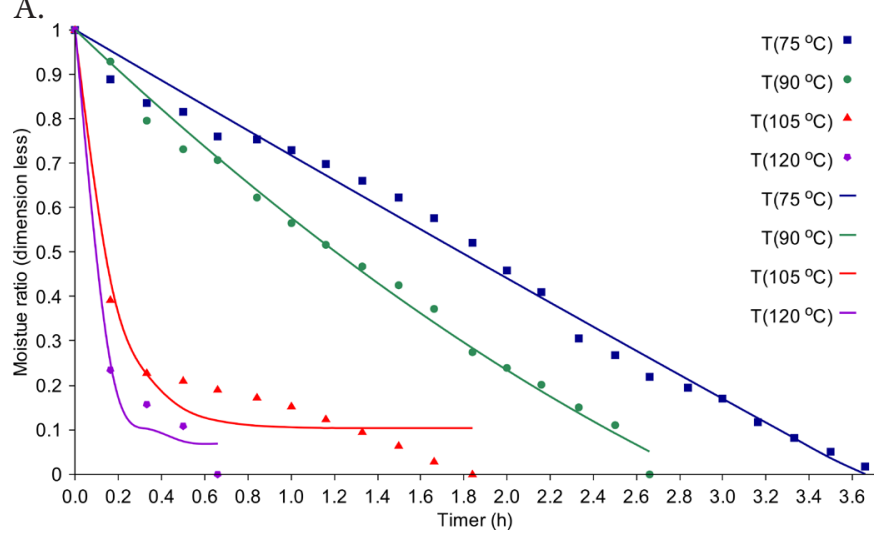

$\mathrm{B}_{\mathrm{i}}$

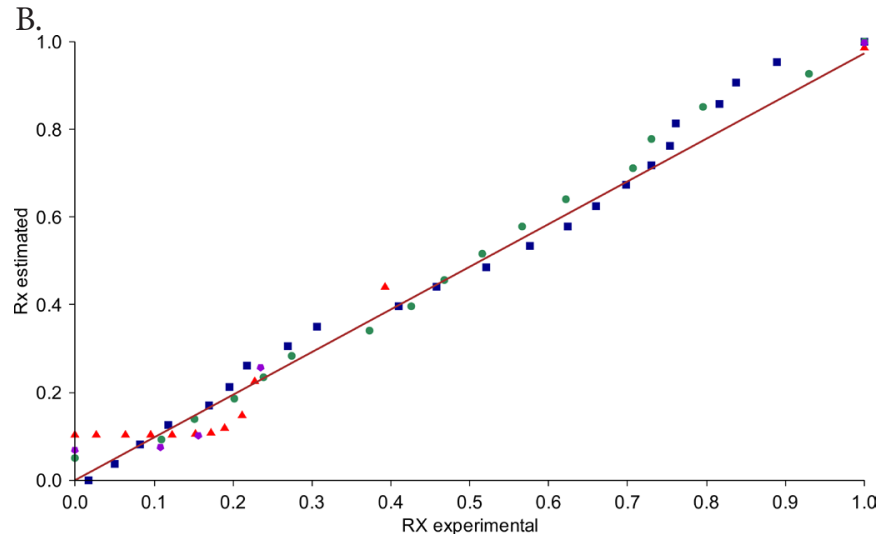

Figure 3. Moisture ratio (A) adjusted, experimental data and estimated moisture ratio (B) to the Wang \& Singh model, for $25 \%$ (d.b.) of initial moisture content

drying rate compared to the product being dried at higher temperatures. The Wang \& Singh model showed better fit to the experimental data at drying temperatures of 75, 90, 105 and 120 ${ }^{0} \mathrm{C}$ and initial water content of $25 \%$ (d.b.) of soybean, showing similarity to the results obtained for drying and initial water content of 19\% (d.b.). In Figures 3A and 3B, it is observed the adjustment of the experimental data and predicted moisture content to the Wang \& Singh model to describe the drying of the soybean grains with initial water content of $25 \%$ (d.b.). It was found that the coefficient of determination was above 0.99 , the mean relative error $(\mathrm{P})$ and estimated average values of error (SE) were below $10 \%$ and residues were randomly distributed (Table 2).

It can be seen in Figure $4 \mathrm{~A}$ that the temperature of 120 ${ }^{\circ} \mathrm{C}$ showed the highest effective diffusivity $\left(2.5 \times 10^{-11} \mathrm{~m}^{2}\right.$ $\mathrm{s}^{-1}$ ), indicating that the drying process in these conditions was faster than in the others. This result is consistent, since the temperature of the drying air of $120^{\circ} \mathrm{C}$ was the highest one. When comparing the initial moisture contents of 25 and $19 \%$ (d.b.), it was found that increasing the moisture in the grains also increases the diffusivity. On the other hand, the drying temperature of $75^{\circ} \mathrm{C}$ showed the lowest value of effective diffusivity $\left(1.7 \times 10^{-11} \mathrm{~m}^{2} \mathrm{~s}^{-1}\right)$ (Figure $\left.4 \mathrm{~A}\right)$. It was verified that values of $\ln (\mathrm{D})$ as a function of the inverse absolute temperature $(1 / \mathrm{Ta})$ showed similar behavior for the ranges of temperature 75 to $90^{\circ} \mathrm{C}$ and 105 to $120^{\circ} \mathrm{C}$ for initial moisture content of $25 \%$ (d.b.) (Figure 4B). According to Figure $4 \mathrm{C}$, reducing the moisture content in the grains increased the energy necessary for the removal of water from

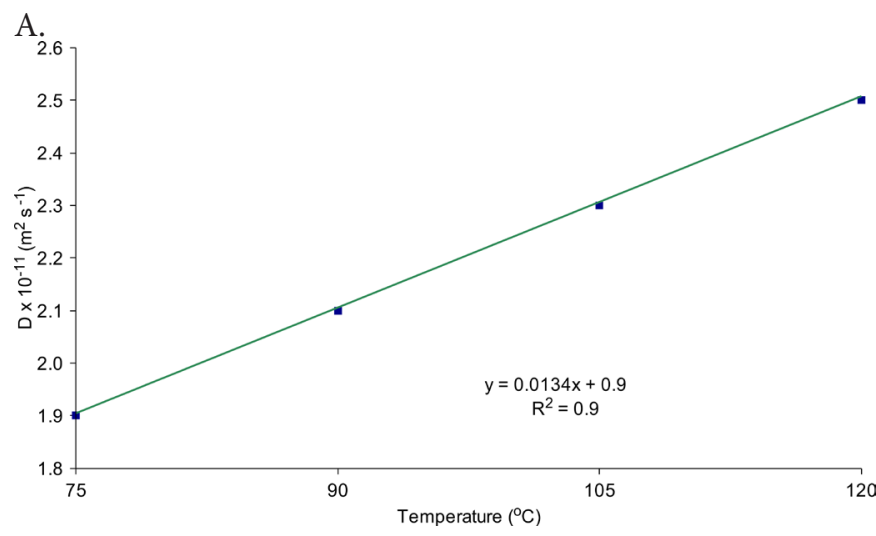

B.

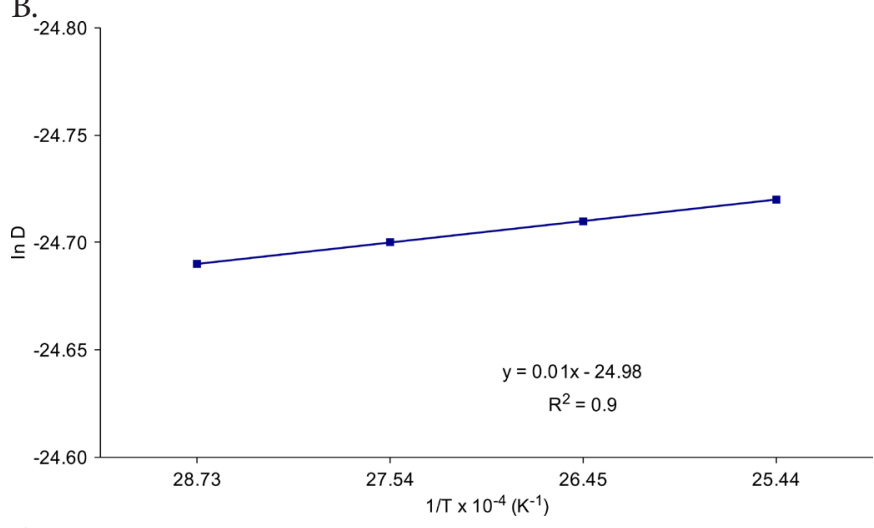

C.

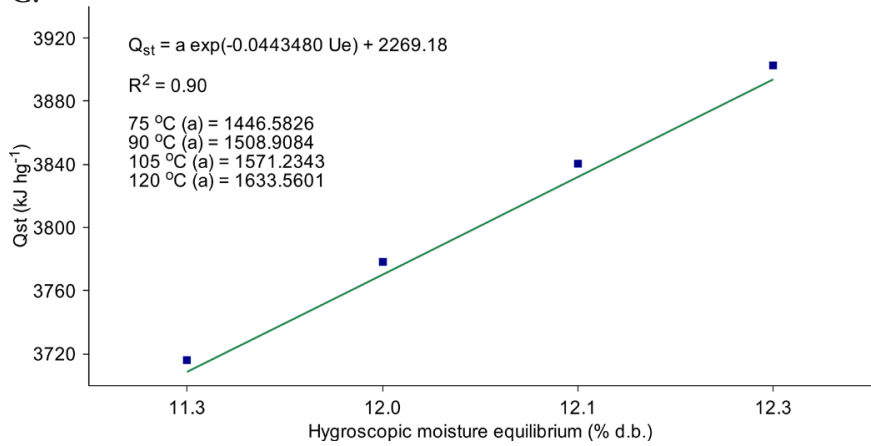

Figure 4. Mean values for the effective diffusion coefficient $\left(\mathrm{m}^{2} \mathrm{~s}^{-1}\right)(\mathrm{A})$, representation of the Arrhenius relationship for the effective diffusivity (B), experimental values and estimated integral isosteric heat of desorption as a function of equilibrium moisture content (C), due to different air temperatures in the drying for $25 \%$ (d.b.) of initial moisture content of soybeans grains

the product, represented by integral values of the isosteric heat of desorption $\left(\mathrm{Q}_{\mathrm{st}}\right)$ (Figure $4 \mathrm{C}$ ) as observed for several agricultural products.

To remove water from grains with low moisture content, more energy is necessary on average than that required for wet products. These results confirm that, in products with higher moisture content, the force between water molecules and dry material decreases significantly. According to Table 3 , it was observed that the variations of oil content for different temperatures and initial moisture contents were not significant at 0.01 and 0.05 probabilities.

The results obtained in this study (Table 4) confirm those reported in the literature, not detecting immediate effect of drying methods on the yield of soybean oil. Similar results were observed by Oliveira et al. (2013), who studied the effect of five 
Table 3. Analysis of variance of oil yield (\%) of soybeans after drying (12\% d.b.)

\begin{tabular}{|c|c|c|c|c|c|}
\hline$\overline{V F}$ & $\overline{D F}$ & SS & $\overline{M S}$ & $\overline{C F}$ & $\mathrm{P}>\mathrm{CF}$ \\
\hline Temperature & 3 & 24.788708 & 8.262903 & 1.498 & $0.2320^{\mathrm{NS}}$ \\
\hline Moisture & 1 & 4.326130 & 2.163065 & 0.392 & $0.6785^{\text {NS }}$ \\
\hline Temperature* moisture & 2 & 4.016089 & 4.016089 & 0.728 & $0.3993^{\mathrm{NS}}$ \\
\hline Error & 30 & 193.019392 & 5.514840 & & \\
\hline Total corrected & 35 & 226.150318 & & & \\
\hline
\end{tabular}

drying temperatures of soybean (ambient air, 40, 60, 80 and $100^{\circ} \mathrm{C}$ ) and reported that the yield of soybean oil with drying temperature not above $40{ }^{\circ} \mathrm{C}$ was significant; however, this value was more visible from a period of more than eight months of storage. When evaluating the effect of temperature on grain drying (20-25, 35-40, 55-60 and 75-80 $\left.{ }^{\circ} \mathrm{C}\right)$, Zeni (2010) also found no statistically significant difference in an immediate effect of the drying process. Pohndorf (2012), studying the yield of soybean oil extracted from grain stored at different moisture contents (12 and $16 \%$ d.b.) and temperatures $(8,13$, 18,23 and $28^{\circ} \mathrm{C}$ ) found no statistically significant difference between the treatments employed.

In Table 5, it was observed significant variations of the variance at 0.01 probability for the results of electrical conductivity between the drying treatments with different temperatures and with different initial moisture contents.

Analysing the results of Table 6, it was observed that increasing the drying air temperature increased electrical conductivity values of the soybeans.

The increase in electrical conductivity may be implicated in the major damage caused by the drying air temperature on the cellular structure of the grains during drying, causing them to lose physiological and nutritional quality (Barbosa et al., 2014). Likewise, it was found that higher initial contents of water increase the risk of deterioration of grains during drying, due to the longer exposure to the temperatures of the drying air. Ullmann et al. (2010) reported a reduction in the percentage of germination of Jatropha while there was an increase in electrical conductivity. According to the authors,

Table 4. Average results for oil yield (\%) in soybean after drying ( $12 \%$ d.b.) at different temperatures

\begin{tabular}{ccc}
\hline $\begin{array}{c}\text { Air drying } \\
\text { temperature }\left({ }^{\circ} \mathbf{C}\right)\end{array}$ & $\begin{array}{c}\text { Initial water content } \\
(\mathbf{1 9 \%} \text { d.b.) }\end{array}$ & $\begin{array}{c}\text { Initial water content } \\
\mathbf{( 2 5 \%} \mathbf{d . b} .)\end{array}$ \\
75 & $15.37 \mathrm{Aa}$ & $15.73 \mathrm{Aa}$ \\
90 & $15.59 \mathrm{Aa}$ & $15.41 \mathrm{Aa}$ \\
105 & $15.20 \mathrm{Aa}$ & $15.25 \mathrm{Aa}$ \\
120 & $15.69 \mathrm{Aa}$ & $15.37 \mathrm{Aa}$ \\
\hline
\end{tabular}

Means followed by the capital letter in the column for each temperature air drying and lowe lines for each initial water content, do not differ at 0.01 and 0.05 probability

Table 5. Analysis of variance of the electrical conductivity test $\left(\mu \mathrm{S} \mathrm{cm}^{-1} \mathrm{~g}^{-1}\right)$ in soybeans after drying (12\% d.b.)

\begin{tabular}{lrcrcc}
\hline \multicolumn{1}{c}{ VF } & DF & SS & \multicolumn{1}{c}{ MS } & CF & P $>$ CF \\
Temperature & 3 & 13589.55 & 6794.77 & 6.531 & $0.0044^{\star *}$ \\
Moisture & 1 & 10523.68 & 10523.68 & 10.116 & $0.0034^{\star *}$ \\
Temperature*moisture & 2 & 24123.01 & 12061.50 & 11.594 & $0.0002^{* *}$ \\
Error & 30 & 31209.66 & 1040.32 & & \\
Total corrected & 35 & 79445.91 & & &
\end{tabular}

Coefficient variation $(\%)=7.26,{ }^{* *}$ Significant at 0.01 probability; VF - Variation function; DF - Degrees of freedom; SS - Sum of squares; MS - Mean squares; CF - Calculated F; $P$ - Probability
Table 6. Average results of the electrical conductivity test $\left(\mu \mathrm{S} \mathrm{m}^{-1} \mathrm{~g}^{-1}\right)$ in soybeans after drying $(12 \%$ d.b.) at different temperatures and initial moisture content (\% d.b.)

\begin{tabular}{ccc}
\hline $\begin{array}{c}\text { Air drying } \\
\text { temperature }\left({ }^{\circ} \mathrm{C}\right)\end{array}$ & $\begin{array}{c}\text { Initial water content } \\
(\mathbf{1 9 \%} \text { d.b.) }\end{array}$ & $\begin{array}{c}\text { Initial water content } \\
(\mathbf{2 5 \%} \text { d.b.) }\end{array}$ \\
75 & $394.17 \mathrm{Aa}$ & $423.24 \mathrm{Ab}$ \\
90 & $412.94 \mathrm{Aa}$ & $457.30 \mathrm{Bb}$ \\
105 & $471.79 \mathrm{Ba}$ & $510.96 \mathrm{Cb}$ \\
120 & $520.19 \mathrm{Ca}$ & $540.35 \mathrm{Db}$ \\
\hline
\end{tabular}

Means followed by the capital letter in the column for each temperature air drying and lower lines for each initial water content, do not differ at 0.01 probability

the damage at the cellular level in seeds caused by the removal of water from their interior initially can cause physiological and biochemical changes that can be identified by the electrical conductivity test and not be clearly seen in the germination test.

\section{Conclusions}

1. The initial moisture content of the product interferes with the drying time, and the higher the temperature of the drying air $\left(120^{\circ} \mathrm{C}\right)$ and lower the initial moisture content of the grains $(19 \%$ d.b. $)$, the faster the product reaches the water balance level.

2. The model of Wang \& Singh proved to be more suitable to describe the drying of soybeans for temperature ranges of the drying air.

3. The effective diffusivity obtained from the drying of soybeans was higher $\left(2.5 \times 10^{-11} \mathrm{~m}^{2} \mathrm{~s}^{-1}\right)$ at a temperature of $120{ }^{\circ} \mathrm{C}$ and water content of $25 \%$ (d.b.).

4. Drying of soybeans at higher temperatures (above $105{ }^{\circ} \mathrm{C}$ ) and higher initial moisture content (25\% d.b.) also increases the amount of energy (3894.57 $\left.\mathrm{kJ} \mathrm{kg}^{-1}\right)$, i.e., the isosteric heat of desorption necessary to carry out the process.

5. High influence of air temperature and of different initial moisture contents affected the quality of soybean along the drying time (electrical conductivity of $540.35 \mu \mathrm{S} \mathrm{cm}^{-1} \mathrm{~g}^{-1}$ ), however, does not affect the final yield of the oil extracted from soybean grains (15.69\%).

\section{ACKNOWLEDGEMENT}

The authors thank the FUNDECT - MS for the financial support for the development of this research.

\section{Literature Cited}

Almeida, D. P.; Resende, O.; Costa, L. M.; Mendes, U. C.; Sales, J. F. Cinética de secagem do feijão adzuki (Vigna angularis). Global Science and Technology, v.2, p.72-83, 2009.

Babalis, S. J.; Belessiotis, V. G. Influence of the drying conditions on the drying constants and moisture diffusivity during the thin-layer drying of figs. Journal of Food Engineering, v.65, p.449-458, 2004. http://dx.doi.org/10.1016/j.jfoodeng.2004.02.005

Barbosa, R. M.; Silva, C. B.; Medeiros, M. A.; Centurion, M. A. P. C.; Vieira, R. D. Condutividade elétrica em função do teor de água inicial de sementes de amendoim. Ciência Rural, v.42, p.45-51, 2014. http://dx.doi.org/10.1590/S0103-84782012000100008

Brasil. Ministério da Agricultura e Reforma Agrária. Regras para análise de sementes. Brasília: SNDA/DNDV/CLAV, 2009. 
Brooker, D. B.; Bakker-Arkema, F. W.; Hall, C. W. Drying and storage of grains and oilseeds. Westport: The AVI Publishing Company, 1992. 450p.

CONAB - Acompanhamento da safra brasileira: grão safra 2013/2014, segundo levantamento, novembro 2013. Brasília, 2013. <http:// www.conab.gov.br>. 17 Mar. 2014.

Coradi, P. C.; Borém, F. M.; Reinato, C. H. Coffee cherries drying process and the influence of environment relative humidity in the mathematical modeling, moisture content, and enthalpy of vaporization. Energia na Agricultura, v.29, p.148-157, 2014 b. http://dx.doi.org/10.17224/energagric.2014v29n2p148-157

Coradi, P. C.; Melo, E. C.; Rocha, R. P. Evaluation of electrical conductivity as a quality parameter of lemongrass leaves (Cymbopogon Citratus Stapf) submitted to drying process. Drying Technology, v.32, n.8, p.969-980, 2014a. http://dx.doi.org/10.108 0/07373937.2013.879593

Corrêa, P. C.; Goneli, A. L. D.; Afonso Júnior, P. C.; Oliveira, G. H. H.; Valente, D. S. M. Moisture sorption isotherms and isosteric heat of sorption of coffee in different processing levels. International Journal of Food Science and Technology, v.45, p.2016-2022, 2010. http://dx.doi.org/10.1111/j.1365-2621.2010.02373.x

Corrêa, P. C.; Resende, O.; Ribeiro, D. M. Drying characteristics and kinetics of coffee berry. Revista Brasileira de Produtos Agroindustriais, v.8, p.1-10, 2006. http://dx.doi.org/10.15871/15178595/rbpa.v8n1p1-10

Goneli, A. L. D.; Corrêa, P. C.; Magalhães, F. E. A.; Baptestini, F. M. Contração volumétrica e forma dos frutos de mamona durante a secagem. Acta Scientiarum. Agronomy, v.33, p.1-8, 2011. http:// dx.doi.org/10.4025/actasciagron.v33i1.4629

Kashaninejad, M.; Mortazavi, A.; Safekordi, A.; Tabil, L. G. Thin - Layer drying characteristics and modeling of pistachionuts. Journal of Food Engineering, v.78, p.98-108, 2007. http://dx.doi. org/10.1016/j.jfoodeng.2005.09.007

Martinazzo, A. P.; Melo, E. C.; Corrêa, P. C.; Santos, R. H. S. Modelagem matemática e parâmetros qualitativos da secagem de folhas de capim-limão Cymbopogon citratus D. C. Stapf. Revista Brasileira de Plantas Medicinais, v.12, p.488-498, 2010. http:// dx.doi.org/10.1590/S1516-05722010000400013
Mohapatra, D.; Rao, P. S. A. Thin layer drying model of parboiled wheat. Journal of Food Engineering, v.66, p.513-518, 2005. http:// dx.doi.org/10.1016/j.jfoodeng.2004.04.023

Oliveira, D. E. C.; Resende, O.; Souza, S. T. A.; Siqueira, V. C.; Neto, C. A. J. Alterações morfométricas em grãos de soja durante o processo de secagem. Semina: Ciências Agrárias, v.3, p.975-984, 2013. http:// dx.doi.org/10.5433/1679-0359.2013v34n3p975

Nascimento, V. R. G.; Biagi, J. D.; Oliveira, R. A. de. Modelagem matemática da secagem convectiva com radiação infravermelha de grãos de Moringa oleifera. Revista Brasileira Engenharia Agrícola Ambiental, v.19, p.686-692, 2015. http://dx.doi. org/10.1590/1807-1929/agriambi.v19n7p686-692

Pohndorf, R. S. Efeitos da umidade e do resfriamento no armazenamento sobre a qualidade de grãos e do óleo de soja para fins comestíveis e de produção de biodiesel. Pelotas: FAEM/ LCTQ/UFPEL, 2012. 71p. Dissertação Mestrado

Radünz, L. L.; Melo, E. C.; Rocha, P. P.; Berbert, P. A.; Gracia, L. M. N. Study of essential oil from guaco leaves submitted to different drying air temperature. Engenharia na Agricultura, v.18, p.241247, 2010. http://dx.doi.org/10.13083/1414-3984.v18n03a07

Reis, R. C.; Barbosa, L. S.; Lima, M. L.; Reis, J. S.; Devilla, I. A.; Ascheri, D. P. R. Modelagem matemática da secagem da pimenta Cumari do Pará. Revista Brasileira de Engenharia Agrícola e Ambiental, v.15, p.347353, 2011. http://dx.doi.org/10.1590/S1415-43662011000400003

Siqueira, V. C.; Resende, O.; Chaves, T. H. Drying kinetics of Jatropha seeds. Revista Ceres, v.59, p.171-177, 2012. http://dx.doi. org/10.1590/S0034-737X2012000200004

Ullmann, R.; Resende, O.; Sales, J. F.; Chaves, T. H. Qualidade das sementes de pinhão manso submetidas à secagem em diferentes condições de ar. Revista Ciência Agronômica, v.41, p.442-447, 2010. http://dx.doi.org/10.1590/S1806-66902010000300017

Vieira, R. D.; Krzyzanowski, F. C. Teste de condutividade elétrica. (Electrical conductivity test). In: Vieira, R. D.; Krzyzanowski, F. C.; França Neto, J. B. Vigor de sementes: conceitos e testes. Londrina: ABRATES, v.4, p.1-26, 1999.

Zeni, D. B. Efeitos da temperatura na secagem e da umidade relativa no armazenamento sobre a qualidade de grãos e óleo de canola para biocombustível. Pelotas: FAEM/LCTQ/UFPEL, 2010. 82p. Dissertação Mestrado 